\title{
STATUS PEMANFAATAN LABI-LABI (FAMILI: TRIONYCHIDAE) DI SUMATERA SELATAN
}

\author{
Dian Oktaviani') dan Samedi²) \\ 1) Peneliti pada Pusat Riset Perikanan Tangkap, Ancol-Jakarta \\ 2) Peneliti pada Balai Konservasi Sumber Daya Alam DKI Jakarta, Jakarta
}

Teregristrasi I tanggal: 20 Nopember 2007; Diterima setelah perbaikan tanggal: 1 April 2008; Disetujui terbit tanggal: 15 Mei 2008

\section{ABSTRAK}

Sumatera Selatan merupakan salah satu pemasok labi-labi (Testudines; Trionychidae) bagi pasar internasional, sedangkan informasi mengenai pemanfaatan sedikit. Tujuan dari penelitian ini adalah untuk mengetahui status pemanfaatan labi-labi (Testudines; Trionychidae) di Sumatera Selatan. Penelitian didasarkan pada data perdagangan sebagai bentuk pemanfatan yang dihubungkan dengan keberlanjutan spesies tersebut di alam. Metode yang dilakukan dalam penelitian ini adalah melalui wawancara dengan penangkap dan penampung labi-labi (Testudines; Trionychidae) di Palembang dan sekitar. Pengumpulan data dilakukan dari bulan Februari 2006 - Februari 2007. Hasil menunjukkan bahwa ada tiga spesies labi-labi yang dimanfaatkan sebagai komoditas perdagangan, yaitu Amyda cartilaginea Boddaert 1770, Dogania subplana Geoffroy 1809, dan Pelochelys cantorii Gray 1864. Spesies dominan dimanfaatkan adalah $A$. cartilaginea $(84,28 \%)$ yang masuk dalam daftar Appendiks II CITES. Penilaian Non Detrimental Findings (NDF) terhadap pemanfaatan $A$. cartilaginea mengindikasikan bahwa populasi spesies tersebut di alam terancam kerusakan. Pemecahan yang perlu dilakukan adalah penegakan hukum dan implementasi peraturan yang efektif.

KATA KUNCI: status pemanfaatan, labi-labi, Trionychidae, non detrimental findings, Sumatera Selatan

\section{ABSTRACT: Softshell turtle (Testudines; Trionychidae) utilization in South Sumatera. By: Dian Oktaviani and Samedi}

South Sumatra is one of the major sources of softshell turtle (Testudines; Trionychidae) in international trade, but the little information was available of local utilization. The study was conducted to fill such a gap, especially on the nature of the trade in relation to the sustainability of the population and trade of the species. The research was aimed to identify the level of local and international utilization in several species of soft shell fresh water turtles (Testudines; Trionychidae). The method applied in the research are interview with collectors and local traders located in Palembang and surrounding area. Data collection included field surveys and visits to collectors/traders undertaken from February 2006 to February 2007. The results showed that there were three species of Trionychidae in significant trade. These were Amyda cartilaginea Boddaert 1770, Dogania subplana Geoffroy 1809, and Pelochelys cantorii Gray 1864. It was also found that A. cartilaginea was dominant species compared with the other species, accounted for (84.28\%). Following the inclusion of $A$. cartilaginea in CITES Appendix II determination of Non Detrimental Findings (NDF) was considered essential. It was indicated from the analysis that harvest and subsequent trade in A. cartilaginea population in South Sumatera showed a detrimental trend. One of the solutions is the implementation of effective law enforcement and regulation.

\section{KEYWORDS: $\quad$ utilization state, softshell turtle, Trionychidae, non detrimental findings, South Sumatera}

\section{PENDAHULUAN}

Reptil dalam bentuk hidup, bagian tubuh dan produk olahan telah menjadi komoditas perdagangan yang menguntungkan dan penting di dunia internasional (Mardiastuti \& Soehartono, 2003). Penangkapan yang dilakukan dengan tujuan komersial terhadap spesies tertentu merupakan penyebab utama langka spesies tersebut (Gamble, 2003). Jumlah spesies reptil yang mengalami kepunahan diperkirakan lebih dari 63\% (Reid \& Miller, 1989 dalam
Soehartono \& Mardiastuti 2003). Beberapa spesies reptil terutama jenis kura-kura dan labi-labi yang diperdagangkan dan telah mulai mengalami kelangkaan antara lain Cuora amboinensis, Pelochelys cantorii, Aspideretes gangeticus, dan A. hurum (Rashid \& Khan, 2000; Choudhury et al., 2000).

Indonesia dikenal sebagai salah satu pengeksport reptil terbesar di dunia (Soehartono \& Mardiastuti, 2003). Badan Pusat Statistik (2006) mencatat bahwa eksport reptil hidup pada tahun 2005 ada $703.510 \mathrm{~kg}$ 
yang bernilai US\$1.979.792. Direktorat Jenderal Bea Cukai (2004) menggolongkan reptil hidup dengan kode harmonized system yaitu 0106.20.00.00 dengan sebutan sebagai binatang melata (termasuk ular dan kura-kura atau penyu). Mardiastuti \& Soehartono (2003) mengatakan bahwa Amyda cartilaginea sebagai salah satu reptil yang banyak dieksport dalam kondisi hidup untuk dikonsumsi. Negara tujuan eksport labilabi adalah Cina, Taiwan, dan Singapura (Lau \& Haitao, 2000; Shepherd, 2000) dan Malaysia (Mardiastuti \& Soehartono 2003).

Permintaan pasar terhadap $A$. cartilaginea dipenuhi dengan melakukan penangkapan dari alam. Hal tersebut, dapat dilihat dari data statistik perikanan tangkap mengenai produksi kura-kura air tawar (termasuk labi-labi) yang sudah berlangsung selama 2 dekade. Sumatera Selatan tercatat sebagai propinsi yang memasok komoditas tersebut. Sumatera Selatan merupakan salah satu pengeksport kura-kura air tawar (termasuk labi-labi) (Samedi \& Iskandar, 2000; Shepherd, 2000). Total eksport dari Palembang pada tahun 1996 sampai dengan 2005 berjumlah 9.928,523 ton (Oktaviani et al., 2006).

Hasil conference of parties 13 Convention on International Trade in Endangered Species of Wild Fauna and Flora tahun 2004 di Bangkok menetapkan A. cartilaginea masuk ke dalam daftar Appendix II Convention on International Trade in Endangered Species of Wild Fauna and Flora. Hal itu, berarti jumlah spesies dari Trionychidae dalam daftar tersebut bertambah. Anggota Trionychidae lain yang masuk dalam daftar ini adalah Pelochelys cantorii, P. bironi, Chitra chitra, dan C. Indica, sedangkan Dogania subplana tercantum sebagai non Appendiks.

Spesies yang masuk dalam Appendiks II Convention on International Trade in Endangered Species of Wild Fauna and Flora diatur pemanfaatan dengan prinsip non detrimental findings yang sesuai dengan isi Article IV Convention on International Trade in Endangered Species of Wild Fauna and Flora. Prinsip non detrimental findings tersebut dimaksudkan untuk menjamin bahwa perdagangan internasional yang dilakukan tidak akan merusak populasi spesies tersebut di habitat alam. Non detrimental findings salah satunya diterjemahkan dalam bentuk sistem kuota tangkap dan kuota ekspor serta pengaturan peredaran, perlindungan, dan konservasi jenis tersebut. Sejak $A$. cartilaginea dimasukkan ke dalam daftar Appendiks II non detrimental findings ternyata ditemukan adanya perubahan dalam sistem perizinan pemanfaatan, yang sangat mempengaruhi keberlanjutan (sustainability) dari jenis tersebut baik dari sisi perdagangan maupun populasi di habtat alam.
Samedi \& Iskandar (2000) mengatakan bahwa informasi mengenai pemanfaatan skala domestik (lokal) sedikit, sehingga dibutuhkan suatu penelitian. Hal ini, mendorong dilakukan suatu penelitian yang bertujuan untuk mengetahui status pemanfaatan labilabi di tingkat lokal, yaitu di Sumatera Selatan yang walaupun tidak dapat mewakili seluruh tingkat perdagangan, namun diharapkan dapat untuk mengetahui gambaran pemanfaatan di tingkat lokal yang paling berpengaruh terhadap kelestarian populasi. Metode penelitian dilaksanakan dengan wawancara di tempat penampungan labi-labi dan beberapa instansi terkait yang ada di Palembang. Manfaat dari penelitian adalah memberikan informasi mengenai status pemanfaatan labi-labi di Sumatera Selatan sebagai dasar pengembangan kebijakan bagi pemanfaatan secara berkelanjutan.

\section{BAHAN DAN METODE}

\section{Lokasi dan Waktu Penelitian}

Pengambilan data dilakukan di Kotamadya Palembang, Sumatera Selatan (Gambar 1). Palembang merupakan tempat penampungan labi-labi terbesar di Sumatera Selatan. Semua hasil tangkapan yang berasal dari wilayah Sumatera Selatan dijual pada penampung yang ada di kota tersebut. Penampungan labi-labi dipilih sebagai tempat untuk mengumpulkan data, yaitu jenis, morfometrik (panjang dan bobot), dan volume perdagangan secara harian.

Pelaksanaan penelitian dilakukan dengan survei pendahuluan pada pertengahan tahun 2005 untuk memastikan lokasi penelitian. Penelitian secara intensif dilakukan pada bulan Pebruari 2006 sampai dengan Pebruari 2007.

\section{Pengumpulan Data}

Pengumpulan data dilakukan di tempat penampungan labi-labi yang terdapat di Palembang. Metode yang dilakukan adalah wawancara pada semua penampung labi-labi di Palembang yang berjumlah 6 penampung. Di antara 6 penampung tersebut terdapat 1 tempat penampungan terbesar yang dipilih sebagai sumber data harian. Pemilihan sumber data harian didasarkan pada kemampuan dan kesanggupan penampung untuk mengisi log book. Dua karyawan yang bekerja di penampungan tersebut dilatih untuk dijadikan sebagai enumerator. Enumerator bertugas untuk mencatat data harian. Data yang dikumpulkan dibedakan menjadi 2 yaitu data biologi dan data perdagangan selama satu tahun. 


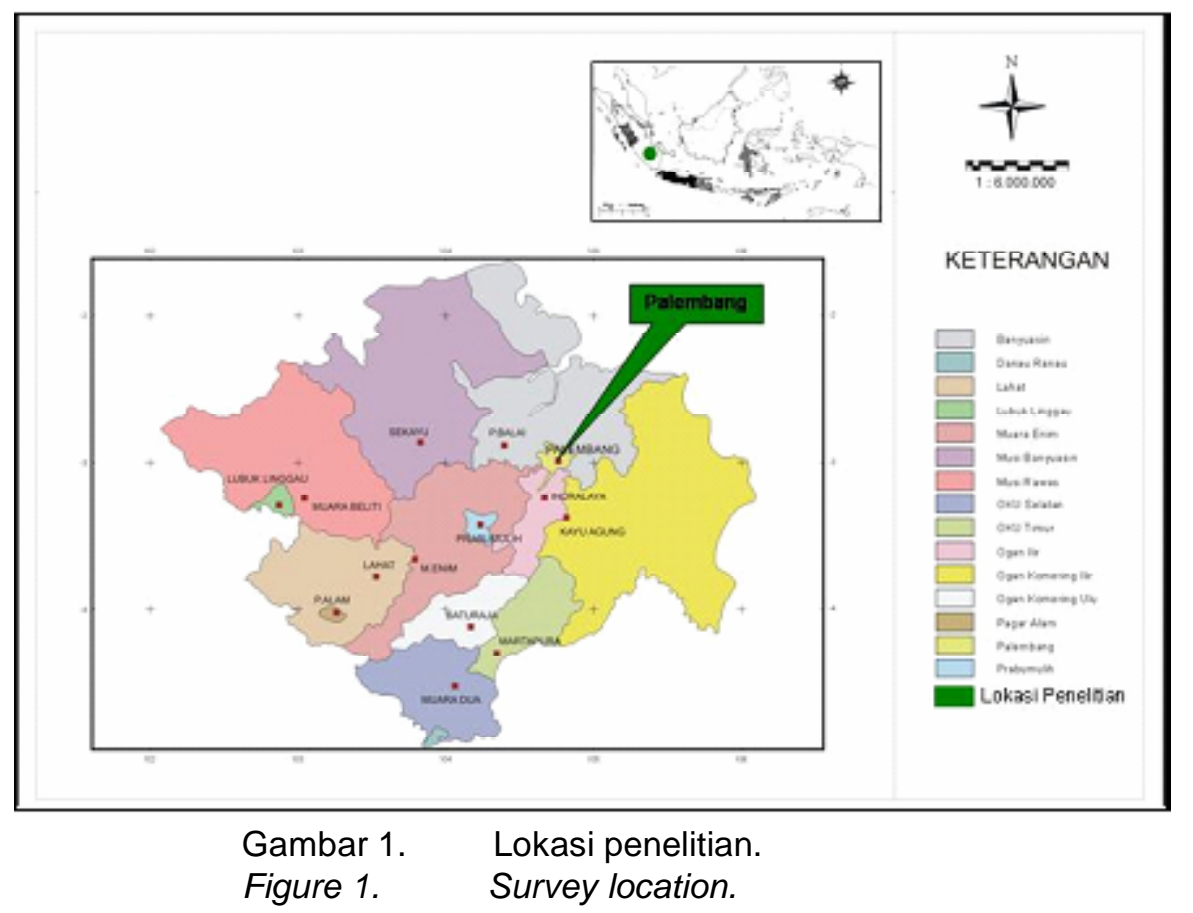

Data biologi terdiri atas jenis, panjang lengkung karapas, dan boboot yang dilakukan oleh 2 orang enumerator secara harian. Enumerator bertugas mengisi log book yang telah disediakan. Pekerjaan enumerator dievaluasi setiap bulan terutama pada saat identifikasi jenis, pengukuran, dan penimbangan.

Data pemanfaatan berupa data perdagangan dilakukan pada 6 penampung labi-labi. Data yang diperlukan adalah jumlah yang masuk, jumlah yang dikirim, dan tempat pengiriman. Khusus data harian perdagangan didapatkan dari penampung yang sama untuk data biologi. Data perdagangan tersebut dicatat dalam kolom isian oleh enumerator. Kelengkapan data perdagangan didapatkan dari instansi terkait, yaitu Dinas Perikanan dan Kelautan Propinsi Sumatera Selatan, Karantina Ikan Bandara Sultan Mahmud Badaruddin II, dan Balai Konservasi Sumber Daya Alam Sumatera Selatan.

\section{Analisis Data}

Data yang didapatkan disusun dalam tabel dengan menggunakan form spreadsheet dari program Microsoft Excel. Data dianalisis secara deskriptif yang disajikan dalam bentuk grafik, diagram alir, foto, dan peta tematik. Khusus data dan informasi mengenai $A$. cartilaginea di Sumatera Selatan dianalisis dengan menggunakan penilaian non detrimental finding (Rosser \& Haywood, 2002). Non detrimental finding merupakan salah satu pertimbangan apakah penetapan kuota pemanfaatan dan tindakan kontrol, konservasi, serta perlindungan $A$. cartilaginea dalam tingkat yang berkelanjutan.

Tujuh komponen non detrimental finding dijabarkan menjadi 26 buah unsur (Lampiran 1). Setiap unsur tersebut diberi nilai yang dimulai dari angka 1 sampai dengan 5 dan diplotkan dalam suatu bentuk grafik radar. Penentuan nilai dari masing-masing unsur ditentukan dari penilaian terbaik (angka 1) sampai dengan penilaian terburuk (angka 5).

Nilai yang telah diberikan kemudian diplotkan dalam bentuk grafik radar. Grafik yang didapat akan dijabarkan bahwa semakin sempit lahan penilaian yang diberikan berarti jaminan terhadap pengambilan suatu spesies di alam tidak akan merusak populasi di alam semakin besar.

\section{HASIL DAN BAHASAN}

\section{Jenis dan Volume Hasil Tangkapan}

Hasil pengisian log book yang dimulai dari pertengahan bulan April 2006 sampai dengan Pebruari 2007 pada satu pengumpul menunjukkan bahwa terdapat 3 jenis labi-labi yang diperdagangkan yaitu Amyda cartilaginea Boddaert 1770, Dogania subplana Geoffroy 1809, dan Pelochelys cantorii Gray 1864 (Gambar 2). Spesies yang paling banyak dipanen dan diperdagangkan adalah $A$. cartilaginea 1.013 ekor $(84,28 \%)$ dari total 1.202 ekor. Jumlah tersebut hanya mencakup hasil tangkapan yang berasal dari Sumatera Selatan. 
Analisis mengenai daerah asal tangkapan ternyata diketahui bahwa labi-labi yang masuk ke penampung tidak hanya berasal dari Sumatera Selatan, tetapi juga datang dari Propinsi Lampung, Jambi, dan Bangka Belitung. Total jumlah labi-labi yang tercatat dari bulan Pebruari 2006 sampai dengan Pebruari 2007 dari tempat penampung yang dijadikan sebagai sumber data dengan memperhitungkan propinsi lain yaitu 2.267 ekor (Gambar 3). Total jumlah tersebut merupakan kombinasi antara data catatan penampung dan pengisian log book.
Data jumlah labi-labi pada bulan Pebruari sampai dengan awal April 2006 ditambahkan dengan volume yang tercatat dalam log book karena data tersebut dicatat berdasarkan pada catatan dari penampung. Data penampung tersebut tidak dibedakan menurut jenis, namun diketahui hasil tangkapan berasal dari Sumatera Selatan. Spesies yang berasal dari luar Sumatera Selatan hanya terdiri atas satu spesies yaitu A. cartilaginea. Hal itu, dikarenakan A. cartilaginea merupakan komoditas yang memiliki permintaan pasar dan harga tertinggi dibanding 2 jenis lain dari famili yang sama.

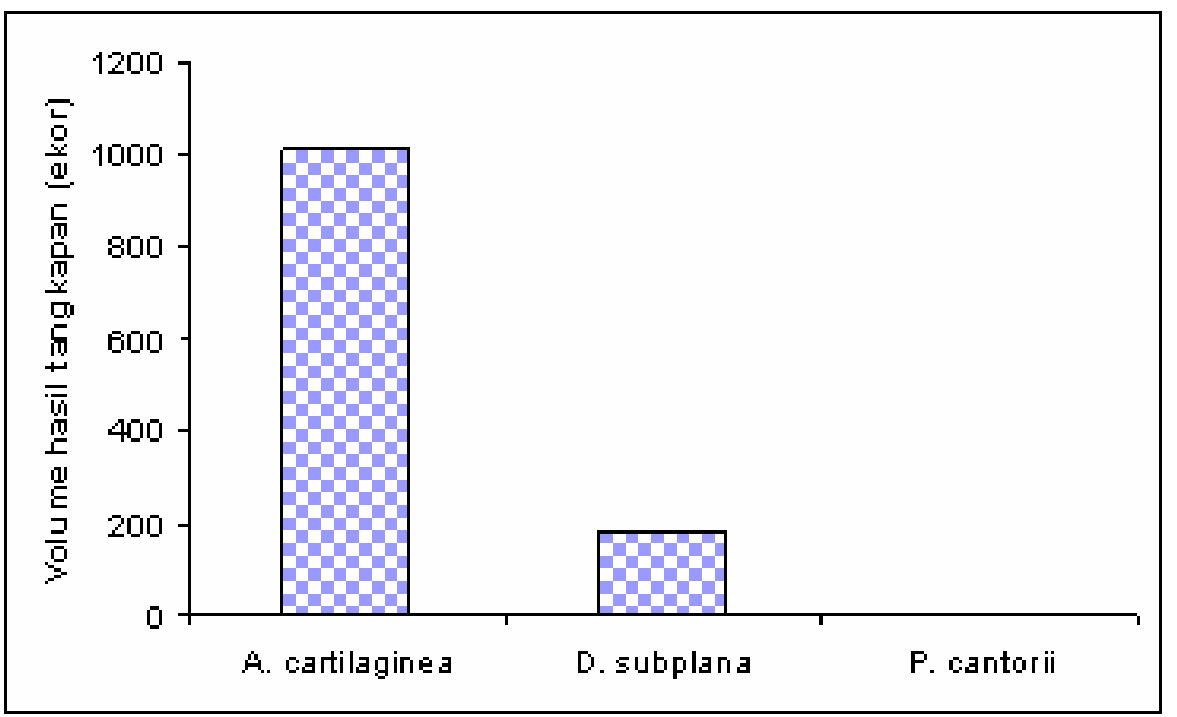

Gambar 2. Jenis labi-labi dan volume tangkapan Sumatera Selatan pada bulan April 2006 sampai dengan Pebruari 2007.

Figure2. Species of softshell turtle and catch volume from South Sumatera in April 2006 until February 2007.

Keberadaan pasokan $A$. cartilaginea yang berasal dari luar Sumatera Selatan juga membuktikan bahwa kontrol antar propinsi tidak efektif. Akan tetapi, khusus untuk Propinsi Bangka Belitung berada dalam 1 manajemen dengan Propinsi Sumatera Selatan karena berada di dalam wilayah kerja dan wewenang Balai Konservasi Sumber Daya Alam Sumatera Selatan.

Perbandingan kuota tangkap $A$. cartilaginea untuk Sumatera Selatan dengan struktur kuota tangkap dari provinsi lain pada tahun 2006 (3,77\%) dari total kuota tangkap Sumatera (Tabel 1). Jumlah tangkapan yang melebihi kuota untuk Sumatera Selatan diduga untuk memenuhi kuota yang berasal dari propinsi lain yang berperan sebagai pintu perdagangan eksport labi-labi yaitu Sumatera Utara. Hal itu, mengindikasikan bahwa penentuan kuota untuk masing-masing propinsi yang tidak efektif telah mengakibatkan terjadi pelanggaran terhadap jumlah kuota tangkap.
Analisis ukuran tubuh $A$. cartilaginea berasal dari Sumatera Selatan yang tercatat selama penelitian dibedakan menjadi 2 kelompok umur berdasarkan pada panjang lengkung karapas. Kelompok umur tersebut adalah muda (PLK<25 cm) dan dewasa (PLK $\geq 25 \mathrm{~cm}$ ) dengan persentase masing-masing 25 dan $75 \%$ (Gambar 4). Persentase kelompok umur dewasa lebih banyak tertangkap daripada kelompok muda. Hal tersebut, dapat mengindikasikan ancaman terhadap rekruitmen populasi $A$. cartilaginea di alam. Ancaman itu berpeluang besar apabila $A$. cartilaginea dewasa yang ditangkap mempunyai kemampuan reproduksi yang tinggi. Hasil wawancara dengan penampung menyebutkan bahwa sering ditemukan $A$. cartilaginea yang mempunyai panjang lengkung karapas $22 \mathrm{~cm}$ atau lebih bertelur di dalam wadah penampungan. Farajallah (2007 komunikasi langsung) mengatakan bahwa $A$. cartilaginea dapat mencapai dewasa setelah panjang karapas setidaknya $20 \mathrm{~cm}$, di mana ukuran tersebut dapat dicapai pada usia 6 tahun. 


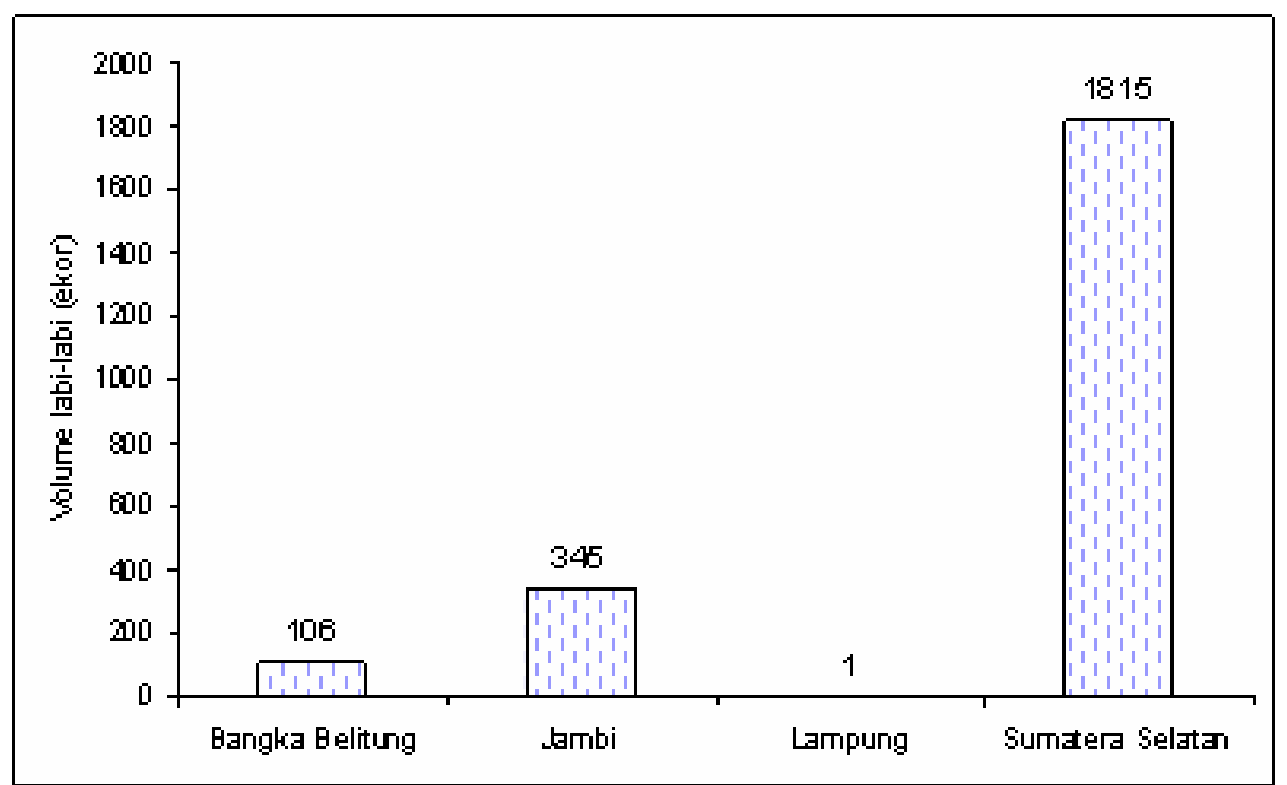

Gambar 3. Volume labi-labi yang tercatat pada bulan Pebruari 2006 sampai dengan Pebruari 2007. Figure 3. Softshell turtle volume in February 2006 until February 2007.

Jenis dan ukuran tubuh menentukan harga dari seekor labi-labi. Tabel 2 memperlihatkan variasi harga untuk setiap ukuran dan $A$. cartilaginea dihargai lebih tinggi daripada $D$. subplana. Menurut keterangan dari penampung bahwa variasi harga tersebut terkait dengan permintaan pasar terutama pasaran eksport. Fluktuasi harga juga dijadikan sebagai alat untuk mengendalikan volume pembelian dari penangkap karena terkait dengan resiko atas kematian labi-labi yang akan ditanggung oleh penampung. Akan tetapi, alasan mengapa pada $A$. cartilaginea berukuran 0,6 sampai dengan $19,9 \mathrm{~kg}$ mempunyai harga yang tinggi bahkan ukuran 3,1 sampai dengan 9,9 kg mencapai harga tertinggi yaitu Rp.44.000,- per kg belum diketahui secara pasti. Salah satu alasan yang menarik yang dikatakan oleh penampung adalah nilai estetika yang berhubungan pada saat penyajian (dish size) dan ukuran tersebut yang mempunyai harga tertinggi di negara importir, sehingga ukuran tersebut yang paling banyak diminati. Bobot $A$. cartilaginea untuk hidangan berukuran antara 1 sampai dengan 3 $\mathrm{kg}$ dengan panjang lengkung karapas 21 sampai dengan $32 \mathrm{~cm}$.

Tabel 1. Kuota tangkap A. cartilaginea untuk propinsi di Sumatera tahun 2006 Table 1. Sumatera Quota for A. cartilaginea in 2006

\begin{tabular}{|c|c|c|c|}
\hline No. & Propinsi/Province & $\begin{array}{c}\text { Kuota tangkap/Catch quota } \\
\text { (ekor) }^{\star}\end{array}$ & $\begin{array}{c}\text { Presentase/Percentage } \\
(\%)\end{array}$ \\
\hline 1. & Sumatera Selatan & 500 & 3,77 \\
\hline 2. & Sumatera Utara I & 6.250 & 47,17 \\
\hline 3. & Sumatera Utara II & 5.000 & 37,74 \\
\hline 4. & Jambi & 1.000 & 7,55 \\
\hline \multirow[t]{2}{*}{5.} & Lampung & 500 & 3,77 \\
\hline & Total & 13.250 & 100 \\
\hline Keter & $\begin{array}{l}\text { * SK Direktorat } \\
\text { wilayah kerja } \\
\text { Daya AlamSur }\end{array}$ & $\begin{array}{l}\text { KA Nomor: SK.15/IV-KKH/2006; Sum } \\
\text { asi Sumber Daya Alam Sumatera Ute }\end{array}$ & $\begin{array}{l}\text { tera Utara I dan II merujuk pada } \\
\text { a I dan Balai Konservasi Sumbe }\end{array}$ \\
\hline
\end{tabular}

Spesies yang tidak mempunyai harga secara khusus yaitu $P$. cantorii, namun dihargai sama dengan $D$. subplana. Alasan yang mendasari rendah harga $P$. cantorii adalah permintaan pasar tidak banyak dan rasa daging yang tidak begitu disukai, selain itu jarang tertangkap sehingga transaksi hampir tidak ada. Data selama penelitian dari bulan April 2006 sampai dengan Pebruari 2007 hanya mencatat 5 ekor $P$. cantoriiyang 
tertangkap. Status spesies tersebut di alam menurut ATTWG (2007) termasuk dalam kategori terancam bahaya kepunahan (endangered), sehingga diduga bahwa populasi dan distribusi jauh lebih kecil dibandingkan dengan $A$. cartilaginea dan $D$. subplana.
Spesies yang mempunyai nilai jual tertinggi adalah A. cartilaginea dibandingkan dengan $D$. subplana karena banyak diminta oleh pasar internasional. Mardiastuti (2007, komunikasi langsung) mengatakan setidaknya ada 2 faktor yang mempengaruhi harga, yaitu trend pasar (permintaan pasar) dan status kelangkaan.

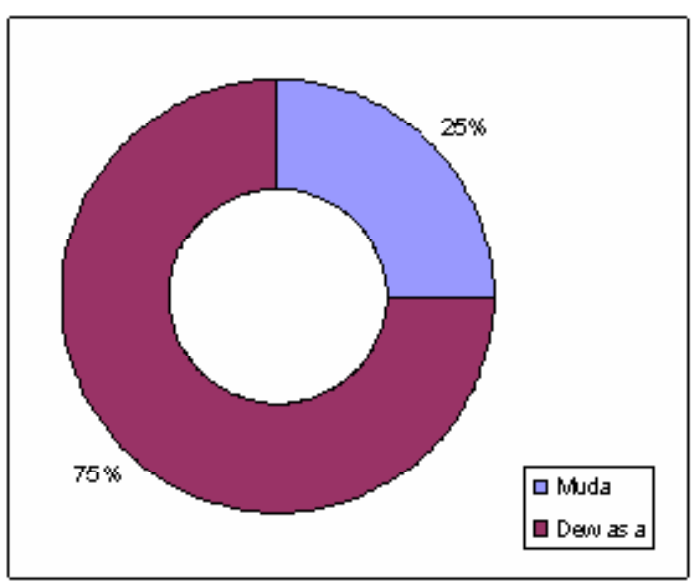

Gambar 4. Frekuensi kelompok umur A. cartilaginea berdasarkan pada panjang lengkung karapas.

Figure 4. $\quad$ Age frequency of $\mathbf{A}$. cartilaginea on curve length carapace.

\section{Hubungan Kuota Pemanfaatan dan Hasil Tangkapan}

Surat Keputusan Direktur Jenderal Perlindungan Hutan dan Konservasi Alam menetapkan kuota pemanfaatan famili Trionychidae di Sumatera Selatan hanya untuk $A$. cartilaginea (Tabel 3 ). Namun demikian, dari hasil penelitian tercatat 2 spesies lain yang ditangkap dan dimanfaatkan, yaitu $D$. subplana dan P. cantorii.
Penghitungan menunjukkan bahwa hasil tangkap tidak sesuai dengan kuota yang ditetapkan, karena ada perbedaan angka yang sangat signifikan antara ke-2. Tabel 3 menunjukkan bahwa jumlah $A$. cartilaginea yang terdapat pada 1 penampung 2 kali lebih besar daripada kuota yang ditetapkan untuk Propinsi Sumatera Selatan, sedangkan ada 2 penampung labi-labi yang besar di Sumatera Selatan. Apabila angka tersebut diekstrapolasikan terhadap 2 penampung berarti volume pemanfaatan 2 kali lipat atau $200 \%$ dari angka kuota yang telah ditetapkan.

Tabel 2. Harga labi-labi di penampung selama pengamatan

Table 2. Softshell turtle price in middleman on survey time

\begin{tabular}{cccc}
\hline No. & $\begin{array}{c}\text { Klasifikasi ukuran/ } \\
\text { Size clasification }(\mathbf{k g})\end{array}$ & $\begin{array}{c}\text { Amyda cartilaginea } \\
(\text { Rp.) per kg }\end{array}$ & $\begin{array}{c}\text { Dogania subplana } \\
\text { (Rp.) per kg }\end{array}$ \\
\hline 1. & $0,1-0,5$ & $5.000-10.000$ & $5.000-7.500$ \\
2. & $0,6-1,0$ & $7.500-15.000$ & $5.000-7.500$ \\
3. & $1,1-3,0$ & $15.000-000$ & $5.000-7.500$ \\
4. & $3,1-9,9$ & $10.000-44.000$ & - \\
5. & $10,0-19,9$ & $7.500-30.000$ & - \\
6. & $20,0-29,9$ & $7.500-16.000$ & - \\
7. & $30,0-40,0$ & $5.000-10.000$ & - \\
8. & $40,0-50,0$ & $3.000-8.000$ & - \\
\hline
\end{tabular}

Volume pemanfaatan yang tercantum dalam Tabel 3 meliputi Propinsi Sumatera Selatan dan Bangka Belitung karena 2 propinsi tersebut merupakan wilayah kerja dari Balai Konservasi Sumber Daya Alam
Sumatera Selatan, sehingga berhubungan dengan kuota tangkap yang ditetapkan. Ketidaksesuaian tersebut menunjukkan ada permasalahan dalam pemanfaatan dan pengelolaan Trionychidae. Tabel 3 
juga memperlihatkan terdapat 2 spesies yang tidak memiliki volume kuota, sedangkan untuk propinsi selain Sumatera Selatan tercantum volume kuota untuk spesies tersebut. Hal itu, akan menyebabkan peluang untuk terjadi data yang tidak dikatakan (unreported).

Hal itu, didukung juga dari data pengiriman dari satu penampung ke tempat tujuan pengiriman (Tabel 4). Perbedaan angka itu menunjukkan bahwa ada kelebihan jumlah individu yang dimanfaatkan. Kelebihan jumlah tangkap ini diduga dimanfaatkan untuk berbagai kepentingan antara lain untuk konsumsi dalam negeri (domestik), pemenuhan kuota propinsi lain atau eksport melalui jalur ilegal.
Jumlah kuota tangkap yang ditetapkan diikuti ukuran yang boleh ditangkap untuk $A$. cartilaginea yaitu bobot $\leq 5 \mathrm{~kg}$. Persentase $A$. cartilaginea yang tercatat untuk volume masing-masing 3 kelompok ukuran tubuh menurut bobot yang berasal dari Sumatera Selatan ternyata didominasi oleh ukuran $<1 \mathrm{~kg}$ yaitu $55 \%$ dari total hasil tangkapan (Gambar 5).

Ukuran $1 \mathrm{~kg}<$ bobot $<5 \mathrm{~kg}$ dan bobot $>5 \mathrm{~kg}$ masingmasing mempunyai persentase 15 dan $30 \%$. Nilai persentase tersebut menunjukkan bahwa $A$. cartilaginea yang ditangkap sebagian besar sudah memenuhi ketentuan ukuran yang ditetapkan yaitu $70 \%$, meskipun volume melebihi kuota tangkap $40 \%$ dari kuota yang ditetapkan untuk tahun 2006.

Tabel 3. Perbandingan antara volume pemanfaatan dan kuota yang ditetapkan pada 2006 Table 3. Catch volume and quota volume in 2006

\begin{tabular}{|c|c|c|c|}
\hline No. & Spesies/Species & $\begin{array}{l}\text { Volume pemanfaatan' } \\
\text { Catch voime (ekor) }\end{array}$ & $\begin{array}{c}\text { Volume Kuotal } \\
\text { Quota volume (ekor) }\end{array}$ \\
\hline 1. & A. cartilaginea & 1.116 & 500 \\
\hline 2. & D. subolana & 184 & - \\
\hline 3. & P. cantorij & 5 & - \\
\hline
\end{tabular}

Gambar 6 memperlihatkan persentase ukuran 1 $\mathrm{kg}<$ bobot $<5 \mathrm{~kg}$ yang mempunyai harga jual tinggi tapi sesuai dengan ketentuan ukuran tangkap berdasarkan pada daerah tangkapan. Keadaan tersebut menjelaskan bahwa Sumatera Selatan hanya dapat memenuhi 32\% dari kuota tangkap yang ditetapkan untuk tahun 2006. Angka 32\% jika diekstrapolasikan dengan ada 2 penampung besar di Sumatera Selatan menjadi $64 \%$ dari kuota tangkap Sumatera Selatan. Angka itu berarti bahwa Sumatera Selatan belum dapat memenuhi kuota tangkap untuk ukuran 1 $\mathrm{kg}<$ bobot $<5 \mathrm{~kg}$.
Data penampung juga mencatat hasil tangkapan yang berasal dari Propinsi Bangka Belitung dan Jambi masing-masing 11 dan $57 \%$ dari kuota tangkap Sumatera Selatan untuk ukuran $1 \mathrm{~kg}<$ bobot<5 kg (Gambar 6). Angka itu berarti bahwa Sumatera Selatan tidak dapat memenuhi kuota tangkap untuk ukuran $1 \mathrm{~kg}<$ bobot<5 kg. Hal tersebut, dapat mengindikasikan bahwa ukuran yang diinginkan pasar sudah sulit didapatkan di alam, sehingga dapat mengancam keberlanjutan pemanfaatan $A$.

Tabel $4 . \quad$ Volume pengiriman dari satu penampung

Table 4. Sending volume from one middleman

\begin{tabular}{|c|c|c|c|c|c|}
\hline \multirow[b]{2}{*}{ No. } & \multirow{2}{*}{$\begin{array}{l}\text { Bulan kirim' } \\
\text { Sending month }\end{array}$} & \multicolumn{2}{|c|}{ Volume } & \multirow{2}{*}{$\begin{array}{l}\text { Spesiesi } \\
\text { Species }\end{array}$} & \multirow{2}{*}{$\begin{array}{c}\text { Tujuani } \\
\ldots \ldots . . .\end{array}$} \\
\hline & & $\begin{array}{c}\text { Bobot } / \\
\text { Weight (kg) }\end{array}$ & $\begin{array}{c}\text { Jumlah' } \\
\text { TotaI (ekor) }\end{array}$ & & \\
\hline 1. & Pebruari 2006 & 1.051 & 263 & A. cartilaginea & Riau \\
\hline 2. & Maret 2006 & 889 & 225 & A. cartilaginea & Riau \\
\hline 3. & April 2006 & $1.649,4$ & 255 & A. cartilaginea & Riau; Jakarta \\
\hline 4. & Mei 2006 & 243,7 & 64 & A. cartilaginea & Riau \\
\hline 5 . & Juni 2006 & 771,9 & $\begin{array}{c}168 \\
36\end{array}$ & $\begin{array}{l}\text { A. cartilaginea } \\
\text { D. subolana }\end{array}$ & Riau; Jakarta \\
\hline 6. & Juli 2006 & 630,45 & 435 & A. cartilaginea & Jakarta \\
\hline 7. & Agustus 2006 & 99,7 & 50 & A. cartilaginea & Riau \\
\hline & Total & $5.335,15$ & 1.496 & & \\
\hline
\end{tabular}


cartilaginea di Sumatera Selatan. Untuk itu, kuota untuk Sumatera Selatan bagi jenis ini dikurangi secara signifikan untuk mengembalikan populasi ke tingkat yang berkelanjutan.

\section{Legalitas Pemanfaatan}

Perubahan status $A$. cartilaginea dari non appendiks menjadi Appendix II Convention on International Trade in Endangered Species of Wild Fauna and Flora yang berlaku sejak bulan Januari 2005 berpengaruh pada instansi pemberi izin dan pengawasan. Izin yang dibutuhkan setelah $A$. cartilaginea masuk ke Appendiks //berpindah ke Balai Konservasi Sumber Daya Alam Sumatera Selatan yang menerbitkan surat izin tangkap dan izin angkut (edar). Penampung labi-labi tidak hanya menampung labi-labi, tapi juga menampung jenis reptil lain seperti kura-kura (selain dari labi-labi), ular, dan biawak. Data dari Balai Konservasi Sumber Daya Alam Sumatera Selatan terdapat 7 penampung yang mempunyai izin untuk memanfaatkan reptil sebagai komoditas perdagangan. Akan tetapi, hanya ada 2 perusahaan yang mempunyai izin memanfaatkan $A$. cartilaginea (Tabel 9).

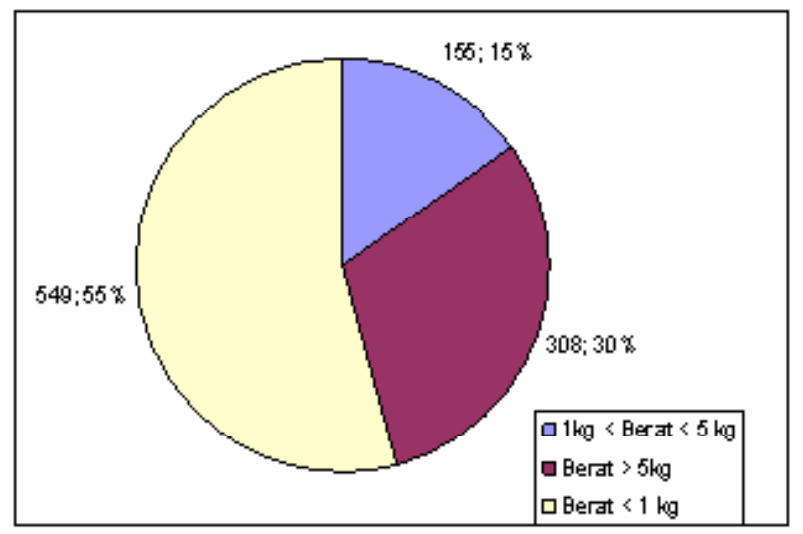

Gambar 5. Volume tangkapan A. cartilaginea di Sumatera Selatan menurut kelompok ukuran bobot. Figure 5. $\quad$ Catch volume of $\mathbf{A}$. cartilaginea weight in South Sumatera.

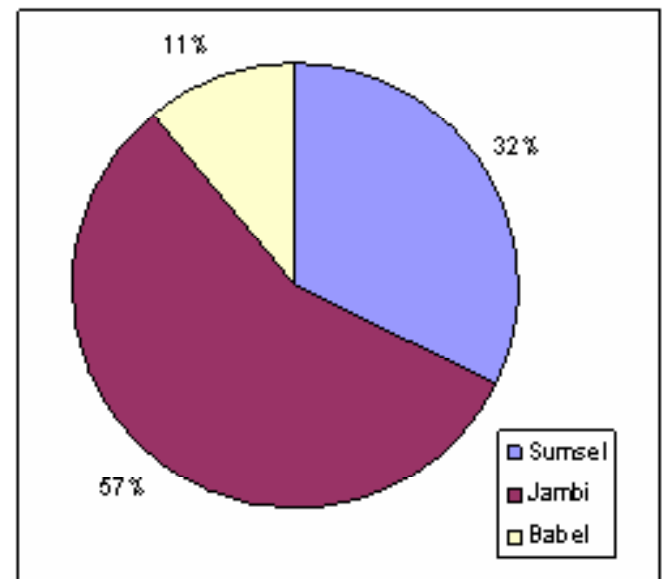

Gambar 6. Persentase pemenuhan kuota tangkap $A$. cartilaginea berukuran $1 \mathrm{~kg}<$ bobot $<5 \mathrm{~kg}$ untuk Sumatera Selatan berdasarkan pada catatan log book

Figure 6. Percentage of $\mathbf{A}$. cartilaginea_with $1 \mathrm{~kg}<$ weight $<5 \mathrm{~kg}$ to fill South Sumatra quota.

Tabel 5 juga menunjukkan bahwa jumlah kuota yang tercantum di dalam Surat Keputusan Direktorat Jenderal PHKA Nomor: SK.15/IV-KKH/2006 dan surat izin Tangkap Balai Konservasi Sumber Daya Alam Sumatera Selatan tahun 2006 lebih kecil dari hasil tangkapan yang masuk ke Palembang baik dari segi jumlah maupun spesies Trionychidae yang dimanfaatkan (ditangkap). Ketidaksesuaian tersebut merupakan pelanggaran terhadap perizinan yang ditegakkan oleh instansi penerbit izin. Penampung wajib mengatakan hasil tangkapan sesuai dengan izin yang diberikan, yang diverifikasi oleh penerbit izin. Konsistensi penegakan peraturan, termasuk perizinan, merupakan salah satu prasyarat untuk pengelolaan sumber daya alam yang baik (good management practice) sehingga keberlanjutan 
populasi dari spesies tersebut dapat dijamin. Upaya penegakan peraturan dengan diberlakukan sanksi bagi yang melanggar, antara lain berupa penyitaan dan pencabutan surat izin tangkap. Meskipun ada sanksi, kenyataan di lapangan volume labi-labi yang dikirim ke luar Sumatera Selatan melebihi dari kuota tangkap yang tercantum dalam surat izin tangkap. Pelanggaran tersebut secara normatif dapat diatasi dengan penegakan hukum yang kuat dan keterlibatan secara aktif dari pihak yang terkait dengan pengawasan. Fauzi (2005) telah mengatakan bahwa penerapan kuota didampingi dengan penegakan hukum yang kuat. Hal itu, dapat menghindarkan terjadi orientasi pada spesies bernilai tinggi (high grading), pengambilan melebihi kuota (quota busting), dan pelaporan yang disembunyikan (under reporting).

Tabel 5. Jumlah penampung (perusahaan) yang terdaftar mempunyai surat izin pemanfaatan reptil di Sumatera Selatan

Table $5 . \quad$ Legality of reptile midllemen in South Sumatera

\begin{tabular}{|c|c|c|c|c|}
\hline $\begin{array}{c}\text { Tahun/ } \\
\text { Year }\end{array}$ & $\begin{array}{c}\text { Penampung/ } \\
\text { Midlemen } \\
\text { (buah) }\end{array}$ & $\begin{array}{c}\text { Penampung yang mempunyai } \\
\text { ijin untuk A. Cartilaginea/ } \\
\text { Reptile midlemen has legality of } \\
\text { A. Cartilaginea } \\
\text { (buah) }\end{array}$ & $\begin{array}{l}\text { Kuota tangkap dari } \\
\text { Direktorat Jenderal } \\
\text { PHKA/Catch quota } \\
\text { from Direktorat } \\
\text { Jenderal PHKA } \\
\text { (ekor) }\end{array}$ & $\begin{array}{l}\text { Kuota tangkap yang } \\
\text { didapat penampung } \\
\text { /Catch quota takes } \\
\text { report mildmen } \\
\text { (ekor) }\end{array}$ \\
\hline \multirow[t]{2}{*}{2005} & 7 & 2 & 2000 & 400 \\
\hline & & & & $1600^{*}$ \\
\hline \multirow[t]{2}{*}{2006} & 7 & 2 & 500 & 75 \\
\hline & & & & $25^{*}$ \\
\hline
\end{tabular}

Keterangan/Remarks: * = pemilik izin berbeda

Sumber/Sources: Balai Konservasi Sumber Daya Alam Sumatera Selatan (2007, tidak dipublikasikan)

Penangkapan berkelanjutan (sustainable harvest) merupakan 1 konsep yang memerlukan pemahaman yang mendalam, namun diikuti dengan implementasi secara praktis oleh multi pihak dan digunakan dalam kegiatan konservasi saat ini yang sering disebut dengan konservasi efektif (effective conservation) (Struhsaker, 1998). Pernyataan Grigg dalam Shine et al. (1999) bahwa kuantifikasi dampak intensitas eksploitasi terhadap densitas populasi dapat dijadikan alternatif untuk memberikan pertimbangan sebagai bahan rekomendasi konservasi. Jadi, keberlanjutan pemanfaatan sumber daya labi-labi berhubungan erat dengan kajian pengaturan penangkapan yang ditinjau dari aspek biologi. Charles (2001) mengatakan bahwa produksi berkelanjutan adalah penangkapan hari ini tanpa merusak sumber daya alam di masa datang. Sehubungan dengan pernyataan-pernyataan di atas dan membandingkan dengan praktek konservasi yang tertuang di dalam sistem perizinan, kontrol, dan perlindungan labi-labi, maka dapat disimpulkan bahwa penangkapan dan pemanfaatan labi-labi di Sumatera Selatan sudah pada tingkat yang tidak berkelanjutan. Hal ini, akan lebih jelas terlihat dari analisis non detrimental finding pada bagian berikut ini.

Upaya pemanfaatan sumber daya labi-labi yang berkelanjutan memerlukan dukungan dan kerja sama yang baik antara komponen yang terlibat langsung di lapangan. Unsur utama yang terlibat dalam sistem dan mekanisme perdagangan labi-labi ada 3, yaitu pemanfaatan (penangkap; penampung), perizinan dan pengawasan. Khusus untuk $A$. cartilaginea berdasarkan pada preferensi persentase volume pemanfaatan berdasarkan pada ukuran yang ditangkap mengindikasikan pada pemanfaatan yang sudah berlangsung melebihi tangkapan berkelanjutan. Hal tersebut, dapat mengancam populasi di alam dan juga pemanfaatan pada masa mendatang.

\section{Penilaian Non Detrimental Finding Amyda cartilaginea Boddaert 1770 di Sumatera Selatan}

Perdagangan internasional jenis-jenis flora dan fauna diatur melalui suatu konvensi internasional yang disebut Convention on International Trade in Endangered Species of Wild Fauna and Flora menjamin keberlanjutan populasi flora dan fauna di habitat alam. Indonesia telah meratifikasi Convention on International Trade in Endangered Species of Wild Fauna and Flora melalui Keputusan Presiden (Kepres) Nomor: 43 tahun 1978 yang berarti Indonesia mengikuti aturan yang ada dalam konvensi tersebut secara efektif. Salah satu isi dari konvensi yang terkait dengan perdagangan satwa yang masuk dalam daftar Appendiks II yaitu Article IV yang mengatakan bahwa pengambilan dan perdagangan internasional terhadap suatu spesies tidak akan merusak populasi di alam yang dikenal dengan istilah non detrimental finding.

Panduan pelaksanaan non detrimental finding telah dikompilasi oleh Rosser \& Haywood (2002). Pelaksanaan non detrimental finding di Indonesia dilakukan oleh Lembaga IImu Pengetahuan Indonesia sebagai Otoritas Keilmuan (Scientific Authority) 
Convention on International Trade in Endangered Species of Wild Fauna and Flora. Komponen utama non detrimental finding dalam menelaah suatu spesies yang ditangkap dari alam menurut Prijono (2005), adalah sifat biologi, status nasional, pengelolaan panen, kontrol panen, pemantauan panen, insentif dan keuntungan panen, serta perlindungan dari panen. Baik buruk pelaksanaan non detrimental finding untuk suatu spesies digambarkan di dalam radar plot yang menghubungkan nilai-nilai dari unsur-unsur non detrimental finding. Gambar radar yang semakin menjauhi titik pusat menggambarkan pelaksanaan non detrimental finding yang buruk.

Penerapan analisis non detrimental finding pada A. Cartilaginea dilakukan dengan menganalisis 26 unsur di atas. Hasil penilaian yang diberikan terhadap A. cartilaginea di Sumatera Selatan (Lampiran) yang digambarkan dalam suatu radar plot (Gambar 7).

Pertimbangan yang dijadikan landasan dalam penilaian untuk 26 unsur non detrimental finding adalah hasil penelitian yang telah dilakukan. Reproduktivitas A. cartilaginea yang membutuhkan waktu 6 tahun untuk mencapai ukuran panjang lengkung karapas $20 \mathrm{~cm}$ (Farajallah, 2007, komunikasi langsung), matang kelamin dengan ukuran PLK $>25 \mathrm{~cm}$, dan umur hidup yang panjang (2.1). Kemampuan untuk beradaptasi terhadap perubahan lingkungan yang cukup baik dan kondisi daerah aliran Sungai yang saling berhubungan (2,2; 2,3; dan 2,4). Distribusi $A$. cartilaginea diketahui meliputi sebagian besar wilayah Sumatera Selatan dan karakteristik habitat secara umum, namun belum diketahui secara pasti distribusi habitat $(2,5)$. Kelimpahan dan populasi yang tergambar dari hasil tangkapan yang ada di penampung (2,6 dan 2,7). Ancaman utama berupa penangkapan, degradasi kualitas habitat, dan konversi lahan basah yang terjadi di Sumatera Selatan terus berlangsung $(2,9)$. Aturan yang ada belum dapat dilaksanakan dengan baik, karena banyak sekali ditemukan ada pelanggaran, contoh pelaporan volume yang tidak sesuai dengan kenyataan di lapangan. Kondisi tersebut juga belum didukung dengan ada aturan tambahan yang menyangkut kesejahteraan (perlakuan yang baik terhadap hewan hidup) hasil tangkapan dan pencatatan jumlah hewan mati selama dalam penampungan $(2,10$ sampai dengan ,20). Peran serta aktif dari penangkap dan penampung dalam upaya konservasi baru terbatas pada konservasi spesies melalui perjanjian kerja sama untuk membuat taman reptil $(2,21 ; 2,22 ; 2,23)$. Aturan jumlah yang boleh ditangkap dari suatu populasi belum ada, meskipun ukuran sudah ada $(2,24)$. Perlindungan yang ketat dan efektivitas aturan yang ada memerlukan kajian khusus $(2,25$ dan 2,26).

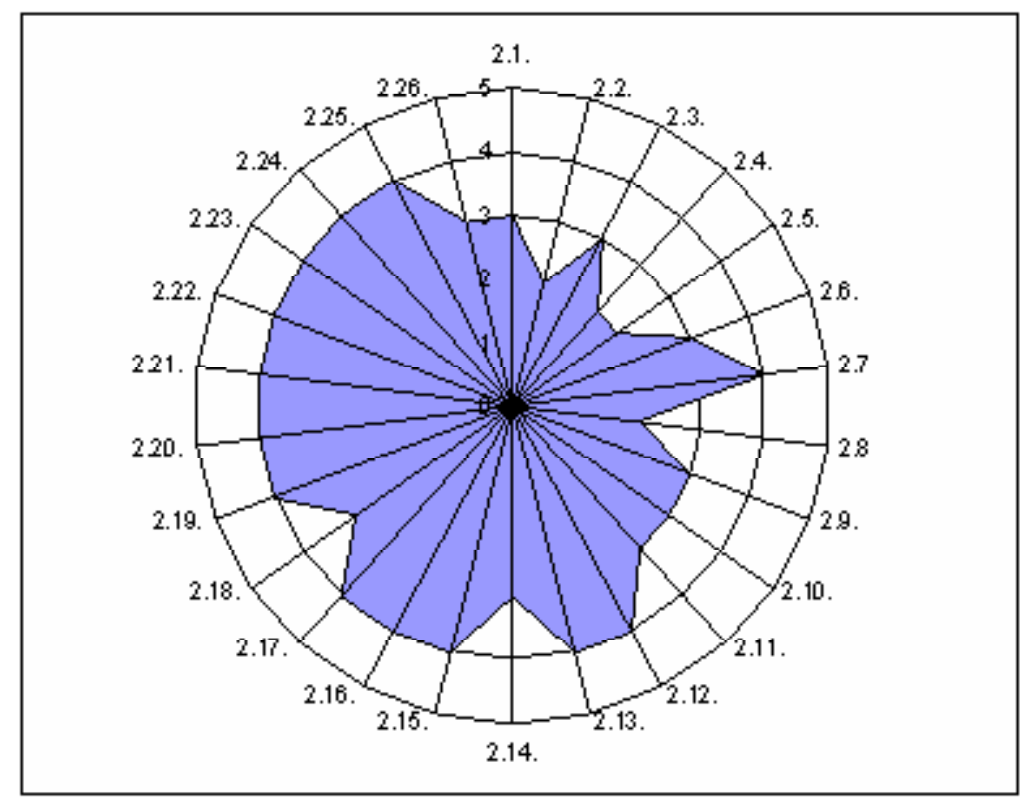

Gambar 7. Radar plot 26 unsur penilaian non detrimental finding terhadap status pemanfaatan $A$. Figure 7. Radar plot of $\boldsymbol{A}$. cartilaginea non detrimental finding state in South Sumatera. 
Hasil analisis yang digambarkan dengan radar plot (Gambar 7) memperlihatkan bahwa daerah yang berwarna biru menjauhi titik pusat. Hal tersebut, mengindikasikan bahwa pemanenan dan perdagangan $A$. cartilaginea di Sumatera Selatan cenderung dapat merusak populasi jenis tersebut di habitat alam. Hal itu, berarti bahwa status pemanfaatan $A$. cartilaginea tidak mengarah pada jaminan terhadap kelestarian populasi di alam. Ini dapat terjadi karena sifat biologi $(2,1$ sampai dengan $2,4)$ dan status $(2,5$ sampai dengan 2,8$) A$. cartilaginea di Sumatera Selatan yang cukup baik, tidak didukung oleh komponen lain (2,9 sampai dengan $2,26)$. Kondisi tersebut memerlukan penanganan yang berpegang pada prinsip kehati-hatian (precautionary principle) seperti yang dikatakan oleh Prijono (2005). Prinsip kehati-hatian yang dimaksud adalah bila dalam keadaan kekurangan informasi suatu jenis organisme, maka lebih baik untuk menunda atau mengurangi pemanenan daripada menanggung resiko kerusakan populasi jenis tersebut di alam.

\section{KESIMPULAN}

1. Tiga jenis Trionychidae yang dimanfaatkan di Sumatera Selatan yaitu Amyda cartilaginea Boddaert 1770, Dogania subplana Geoffroy 1809, dan Pelochelys cantorii Gray 1864 dengan $A$. cartilaginea sebagai jenis yang paling banyak ditangkap dari alam untuk memenuhi permintaan pasar internasional.

2. Sumatera Selatan hanya mampu memenuhi 32 sampai dengan $64 \%$ dari kuota tangkap $A$. cartilaginea yang ditetapkan untuk Sumatera Selatan tahun 2006 untuk ukuran yang paling diminati pasar dan sekaligus sesuai dengan ketentuan ukuran yang boleh ditangkap, namun Sumatera Selatan memasok jauh lebih banyak dari kuota yang ditetapkan karena tidak ada kontrol dan tindakan hukum yang memadai. Oleh karena itu, kuota yang berjumlah 500 ekor merupakan jumlah yang cukup bagi Sumatera Selatan.

3. Status pemanfaatan $A$. cartilaginea di Sumatera Selatan yang dianalisis dengan penilaian non detrimental finding mengindikasikan akan mengancam populasinya di alam. Hal tersebut, terjadi karena faktor biologi $A$. cartilaginea tidak didukung dengan pengelolaan dan tindakan konservasi yang baik.

\section{SARAN}

Pemanfaatan yang berdasarkan pada prinsip non detrimental finding dengan meningkatkan unsur-unsur pengelolaan jenis yang baik seperti kontrol pemanenan, perlindungan terhadap populasi, dan perbaikan habitat perlu dilakukan untuk menjaga populasi semua jenis labi-labi (Trionychidae) di Sumatera Selatan yang diikuti dengan penegakan hukum dan peraturan yang efektif.

\section{UCAPAN TERIMA KASIH}

Penulis mengucapkan terima kasih pada para penampung labi-labi di Palembang, terutama pada Pak Hasan, Pak Joni, Pak Ai, dan Pak Usman, serta semua rekan yang membantu dalam pencatatan dan pengukuran. Tulisan ini tidak akan dapat disampaikan tanpa ada dukungan dari rekan semuanya. Ucapan terima kasih juga untuk Dr. Mirza Dikari Kusrini dari Fakultas Kehutanan-Institut Pertanian Bogor dan Dr. Noviar Andayani dari Fakultas Matematika dan IImu Pengetahun Alam-Universitas Indonesia.

\section{PERSANTUNAN}

Kegiatan dari hasil riset inventarisasi mamalia air (pesut), penyu dan labi-labi, T .A. 2006, di Pusat Riset Perikanan Tangkap-Ancol, Jakarta.

\section{DAFTAR PUSTAKA}

Asian Turtle Trade Working Group. 2000. Pelochelys cantorii. In IUCN 2006. 2006 IUCN Red List of Threatened Species. <http://www.iucnredlist.org/ >. Downloaded on 27 March 2007.

Badan Pusat Statistik. 2006. Statistik perdagangan luar negeri Indonesia. Ekspor 2005. Badan Pusat Statistik. Jakarta. 3.

Charles, A. T. 2001. Sustainable fishery system. Blackwell Science. Ltd. Great Britain. x+370 hlm.

Choudhury, B. C., S. Bhupathy, \& F. Hanfee. 2000. Status information on the tortoises and freshwater turtles of India. Chelonian Research Monograph. 2. 86-94.

Direktorat Jenderal. Bea dan Cukai. 2003. Buku tarif bea masuk Indonesia. Departemen Keuangan. Jakarta. 4.

Direktorat Jenderal Perikanan. 1992-1999. Statistik perikanan Indonesia 1990-1997. Direktorat Jenderal Perikanan. Departemen Pertanian. Jakarta.

Direktorat Jenderal Perikanan Tangkap. 2000-2007. Statistik perikanan tangkap Indonesia 1998-2005. 
Direktorat Jenderal Perikanan Tangkap. Departemen Kelautan dan Perikanan. Jakarta.

Direktorat Jenderal Perlindungan Hutan dan Konservasi Alam. 2004. Keputusan Direktur Jenderal Perlindungan Hutan dan Konservasi Alam Nomor: SK.12.9/IV-KKH/2004 tentang Kuota Pengambilan Tumbuhan Alam dan Penangkapan Satwa Liar untuk Periode Tahun 2005. Direktorat Jenderal PHKA. Departemen Kehutanan. Jakarta.

Direktorat Jenderal Perlindungan Hutan dan Konservasi Alam. 2006. Keputusan Direktur Jenderal Perlindungan Hutan dan Konservasi Alam Nomor: SK.15/IV-KKH/2006 tentang Kuota Pengambilan Tumbuhan Alam dan Penangkapan Satwa Liar untuk Periode Tahun 2006. Direktorat Jenderal PHKA. Departemen Kehutanan. Jakarta.

Fauzi, A. 2005. Kebijakan perikanan dan kelautan: Isu, sintesis dan gagasan. PT. Gramedia Pustaka Utama. Jakarta. ix+187 hlm.

Gamble, T. \& A. M. Somins. 2003. The commercial harvest of painted turtles in Minnesota. Final Report to the Mennesota Department of Natural Resources, Natural Heritage and non game Research Program. Minnesota. ii+40 hlm.

Lau, M \& Shi H. 2000. Conservation and trade of terrestrial and freshwater turtles and tortoises in the people's Republic of China. Chelonian Research Monograph. 2. 30-38.

Mardiastuti, A. \& T. Soehartono. 2003. Perdagangan reptil Indonesia di pasar internasional. Prosiding Seminar Hasil Penelitian. Departemen Konservasi Sumber Daya Hutan. Institut Pertanian Bogor. Bogo. 131-144.

Oktaviani, D, S. Schope, \& M. D. Kusrini. 2006. Kurakura air tawar sebagai komoditas perikanan di Sumatera Selatan. Prosiding Seminar Nasional: Forum Perairan Umum Indonesia III. Palembang. 72-79.
Prijono, S. N. 2005. Precautionary principle, non detriment fibding, dan penetapan kuota pengambilan tumbuhan atau penagkapan satwa. Materi Asistensi Pelaksanaan CITES. Bogor.

Rashid, S. M. A. \& S. M. M. H. Khan. 2000. Trade and concervation status of feshwater turtles and tortoises in Bangladesh. Chelonian Research Monograph. 2. 77-85.

Rosser, A. R. \& Haywood, M. J. (Compilers). 2002. Guidance for CITES scientific authorities: Checklist to assist in making non detriment findings for Appendix II exports. IUCN Gland, Switzerland, and Cambridge, UK, xi+146pp.

Samedi \& Iskandar, D. T. 2000. Freshwater turtle and tortoise conservation and utilization in Indonesia. Chelonian Research Monograph. 2. 106-111.

Samedi \& D. T. Iskandar. 2000. Freshwater turtle and tortoise conservation and utilization in Indonesia. Cheloniain Research Monograph. 2. 106-111.

Shepherd, C. R. 2000. Export of live freshwater turtles and tortoises from North Sumatera and Riau, Indonesia: A case study. Chelonian Research Monograph. 2. 112-119.

Shine, R., Ambariyanto, P. S. Harlow, \& Mumpuni. 1999. Reticulated pythons in Sumatera: biology, harvesting, and sustainability. Elsevier Science. Ltd. Biologi Conservation. 87. 349-357.

Soehartono, T. \& A. Mardiastuti. 2003. Pelaksanaan Konvensi CITES di Indonesia. Japan Internatioanl Cooperation Agency. Jakarta. xxi+317 hlm.

Struhsaker, T. T. 1998. Diversity a biologist's perspective on the role of sustainable harvest in conservation. Conservation Biology. 12. (4). 930932. 
Lampiran1. Penilaian non detrimental finding A. cartilaginea di Sumatera Selatan

Appendix. Non detrimental finding score of A.cartilaginea in South Sumatera.

Spesies : Amyda cartilaginea Boddaert 1770

Lokasi : Sumatera Selatan

\begin{tabular}{lcc}
\hline \multicolumn{1}{c}{ Unsur penilaian non detrimental finding } & Kode & $\begin{array}{c}\text { Nilai } \\
\text { (1-5) }\end{array}$ \\
\hline Biologi-Reproduktivitas dan usia hidup & 2.1 & 3 \\
Biologi-Adaptasi ekologis & 2.2 & 2 \\
Biologi-Efisiensi pemencaran & 2.3 & 3 \\
Biologi-Interaksi dengan manusia & 2.4 & 2 \\
Status-Penyebaran & 2.5 & 2 \\
Status Kelimpahan & 2.6 & 3 \\
Status-Populasi & 2.7 & 4 \\
Status-Kualitas informasi & 2.8 & 2 \\
Status-Ancaman utama & 2.9 & 3 \\
Pengelolaan panen-Panen dan dagang ilegal & 2.10 & 3 \\
Pengelolaan panen-Pengelolaan panen sekarang & 2.11 & 3 \\
Pengelolaan panen-Rencana pengelolaan & 2.12 & 4 \\
Pengelolaan panen-Tujuan batasan panen dalam rencana pengelolaan & 2.13 & 4 \\
Pengelolaan panen-Kuota & 2.14 & 3 \\
Kontrol panen-Pemanenan di kawasan lindung & 2.15 & 4 \\
Kontrol panen-Pemanenan di kawasan milik perorangan atau swasta atau pemda & 2.16 & 4 \\
Kontrol panen-Pemanenan di kawasan milik umum & 2.17 & 4 \\
Kontrol panen-Keyakinan dalam kontrol pemanenan & 2.18 & 3 \\
Pemantauan panen-Metode pemantauan panen & 2.19 & 4 \\
Pemantauan panen-Keyakinan dalam pemantauan panen & 2.20 & 4 \\
Insentif dan keuntungan panen-Manfaat $v s$ ancaman & 2.21 & 4 \\
Insentif dan keuntungan panen-Insentif untuk konservasi jenis & 2.22 & 4 \\
Insentif dan keuntungan panen-Insentif untuk konservasi habitat & 2.23 & 4 \\
Perlindungan dari panen-Persentase yang boleh dipanen dari suatu populasi & 2.24 & 4 \\
Perlindungan dari panen-Keyakinan tentang efektivitas dari pertindungan yang ketat & 2.25 & 4 \\
Perlindungan dari panen-Efektivitas peraturan panen & 2.26 & 3 \\
\hline
\end{tabular}

